\title{
Peripheral neuropathy in chronic occupational inorganic lead exposure: a clinical and electrophysiological study
}

\author{
O Rubens, I Logina, I Kravale, M Eglîte, M Donaghy
}

\begin{abstract}
Background and objectives-Traditionally the neuromuscular disorder associated with lead poisoning has been purely motor. This study assessed peripheral nerve function clinically and electrophysiologically in 46 patients with neuropathic features out of a total population of 151 workers with raised blood and/or urinary lead concentrations.
\end{abstract}

Results-Average duration of occupational exposure for the neuropathic group ranged from 8-47 years (mean 21.7). Their mean blood lead concentration (SD) was 63.9 (18.3) $\mu \mathrm{g} / \mathrm{dl}$ (normal <40), urinary lead 8.6 (3.3) $\mu \mathrm{g} / \mathrm{dl}$ (normal<5.0), urinary coproporphyrins 66.7 (38.4) $\mu \mathrm{g} / \mathrm{g}$ creatinine (20-80), urinary aminolaevulinic acid 1.54 (0.39) $\mathrm{mg} / \mathrm{g}$ creatinine (0.5-2.5). All 46 had distal paraesthesiae, pain, impaired pin prick sensation, diminished or absent ankle jerks, and autonomic vasomotor or sudomotor disturbances. Reduced vibration sensation and postural hypotension were present in all 20 studied. None of these 46 patients had motor anormalities. Motor conduction velocity and compound muscle action potential amplitudes were normal, with marginally prolonged distal motor latencies. Sensory nerve action potential amplitudes lay at the lower end of the normal range, and the distal sensory latencies were prolonged. No direct correlation was found between the biochemical variables, and the clinical or electrophysiological data.

Conclusions-One additional patient was seen with shorter term exposure to lead fumes with subacute development of colicky abdominal pain, severe limb weakness, and only minor sensory symptoms. Unlike the patients chronically exposed to lead, he had massively raised porphyrins (aminolaevulinic acid $21 \mathrm{mg} / \mathrm{g}$ creatinine, coproporhyrins $2102 \mu \mathrm{g} / \mathrm{g}$ creatinine). Patients with unusually long term inorganic lead exposure showed mild sensory and autonomic neuropathic features rather than the motor neuropathy classically attributed to lead toxicity. It is proposed that the traditional motor syndrome associated with subacute lead poisoning is more likely to be a form of lead induced porphyria rather than a direct neurotoxic effect of lead.

(F Neurol Neurosurg Psychiatry 2001;71:200-204)
Keywords: lead toxicity; peripheral neuropathy; porphyria

Traditionally lead poisoning is described as causing a purely motor disorder, often predominating in the arms and selecting heavily used muscles, such as the wrist extensors of painters. ${ }^{1-5}$ At presentation such patients usually have other systemic features such as colicky abdominal pain, constipation, or anaemia. Such disorders have tended to follow subacute or acute high intensity exposure to lead. Sensory abnormalities have not been a noted feature of poisoning with lead, despite their prominence in other heavy metal poisoning neuropathies due to arsenic, mercury, or thallium. $^{6-8}$

Nerve conduction studies have been carried out in chronically exposed industrial workers with raised blood lead concentrations but no clinical evidence of neuropathy. ${ }^{9-13}$ Neurophysiology was normal in many, otherwise showing minimally slowed motor conduction with slightly reduced compound muscle action potentials. These slight abnormalities tended to improve once lead exposure ceased. Abnormalities of sensory nerve action potentials were noted only in a few of these subjects, with slowed conduction rather than reduced amplitude. ${ }^{13}$ Sensory symptoms were generally uncommon in these studies. Criteria for diagnosing lead induced neuropathy have been formulated $^{1}$ : (1) Demonstrable neuropathy on clinical, pathological, or electrophysiological grounds; (2) Involvement of another organ system; (3) exposure corresponding in time to the progression of the disease; removal from exposure should result in stabilisation or remission; (4) an increased tissue or body fluid content of lead.

Confirmed lead induced polyneuropathy has been extremely rare recently due to improved occupational health. However, long term exposure to lead occurred in industrial workers in Latvia until the end of the 1990s. A large cohort of such workers with increased lead concentrations have been followed up ${ }^{14}$ and we were struck by complaints of neuropathic symptoms in nearly a third.

\section{Subjects and methods}

SUBJECTS

One hundred and fifty one subjects with raised blood lead concentrations were registered in Latvia (total population about 2.5 million) by 1998 on the state register of occupational diseases; this represents about $70 \%$ of workers 
in lead risk occupations. The criteria for registration were firstly an occupational exposure to lead and secondly increased blood or urine lead concentrations, or both. The maximum biologically safe lead concentrations in chronically occupationally exposed persons are regarded as $40 \mu \mathrm{g} / \mathrm{dl}$ for blood and $5.0 \mu \mathrm{g} / \mathrm{dl}$ in 24 hour collected urine. ${ }^{214}$ Additionally we measured metabolites of haeme synthesis in urine: $\delta$-aminolaevulinic acid (ALA) (normal 0.5 to $2.5 \mathrm{mg} / \mathrm{g}$ creatinine), and coproporphyrins (CPs) (normal 20-80 $\mu \mathrm{g} / \mathrm{g}$ creatinine). All 151 patients underwent a clinical neurological assessment in the occupational diseases clinic; 103 had no neuropathic symptoms or signs suggesting polyneuropathy. The remaining 48 patients had features suggesting polyneuropathy; we excluded patients with symptoms suggestive of carpal tunnel syndrome (intermittent finger sensory disturbance at night or during manual work). These 48 were screened for other causes of neuropathy by history and routine blood chemistry, including blood sugar; one with diabetes mellitus and one with alcoholism were excluded from further analysis.

BIOCHEMICAL ASSAY

All 151 subjects were investigated periodically, including full blood count, reticulocyte counts, examination for basophilic stippling of erythrocytes, urinary analysis, liver enzymes, and ECG. The concentrations of lead in whole blood and urine were determined by atomic absorption spectrophotometry (Perkin Elmer 403 with graphite furnace HGA 2200) using a deuterium background compensation system. ${ }^{14-16}$ Coproporphyrins and ALA were assayed as described previously. ${ }^{17}{ }^{18}$

CLINICAL ASSESSMENT

Neurological examination of all 151 subjects was performed yearly by OR. Limb power was recorded as $0=$ normal, $1=$ minor symptoms or signs, $2=$ incapable of work or independent walking. Tendon reflexes were graded as $0=$ normal, $1=$ diminished ankle jerk compared with other tendon reflexes, $2=$ absent ankle jerk. Symptoms of paraesthesiae or pain distally in the limbs were recorded as $0=$ absent, $1=$ mild and intermittent, $2=$ continuous without interference with movement or sleep, $3=$ severe, continuous, and intrusive, often needing symptomatic therapy. Pinprick sensation was recorded as $0=$ normal, $1=$ blunted distally, $2=$ lost distal pain sensation. Vibration sense was tested at the metatarsophalangeal joints using a standard camertone $\mathrm{C}_{128}$ tuning fork in 20 patients (normal>10 seconds). Coldness, skin colour, and marmorisation or hyperhydrosis of limb skin were recorded. Blood pressure was tested in lying and standing positions in 20 patients. Involvement of other organ systems was noted: mood or sleep disturbances, abnormal liver or kidney function tests, hypertension, gastrointestinal disturbance, and abnormal haematological indices.
Table 1 Patient characteristics and clinical features

\begin{tabular}{|c|c|}
\hline \multicolumn{2}{|c|}{ Patient characteristics $(n=46)$} \\
\hline Men & $16(35 \%)$ \\
\hline Women & $30(65 \%)$ \\
\hline \multicolumn{2}{|l|}{ Ages $(y)$ : } \\
\hline Mean ((SD)) & $50.3(6.9)$ \\
\hline Range & $30-60$ \\
\hline $30-39$ & $2(4 \%)$ \\
\hline $40-49$ & $16(35 \%)$ \\
\hline $50-59$ & $25(54 \%)$ \\
\hline $60-69$ & $3(7 \%)$ \\
\hline \multicolumn{2}{|c|}{ Duration of ocupational exposure (y): } \\
\hline Mean $((\mathrm{SD}))$ & $21.7(8.7)$ \\
\hline Range & $8-47$ \\
\hline $0-10$ & $4(9 \%)$ \\
\hline $11-20$ & $21(46 \%)$ \\
\hline $21-30$ & $14(30 \%)$ \\
\hline$>31$ & $7(15 \%)$ \\
\hline \multicolumn{2}{|l|}{ Occupations: } \\
\hline Solderers & $25(54 \%)$ \\
\hline Typesetters & $5(11 \%)$ \\
\hline Oxyacetylene cutters & $4(9 \%)$ \\
\hline Enamel makers & $3(6.5 \%)$ \\
\hline Battery workers & $3(6.5 \%)$ \\
\hline Car paint workers & $2(4 \%)$ \\
\hline Others & $4(9 \%)$ \\
\hline Clinical features $(n=46)$ & Number affected (\%) \\
\hline \multicolumn{2}{|l|}{ Symptoms: } \\
\hline \multicolumn{2}{|l|}{ Paraesthesiae } \\
\hline Absent & $0(0)$ \\
\hline Mild & $9(20)$ \\
\hline Moderate/severe & $37(80)$ \\
\hline \multicolumn{2}{|l|}{ Pain } \\
\hline Absent & $0(0)$ \\
\hline Mild & $21(46)$ \\
\hline Moderate/severe & $25(54)$ \\
\hline \multicolumn{2}{|l|}{ Cold dysaesthesia } \\
\hline Absent & $1(2)$ \\
\hline Present & $45(98)$ \\
\hline \multicolumn{2}{|l|}{ Increased foot sweating } \\
\hline Absent & $3(7)$ \\
\hline Present & $43(93)$ \\
\hline \multicolumn{2}{|l|}{ Signs: } \\
\hline \multicolumn{2}{|l|}{ Pinprick sensations } \\
\hline Normal & $0(0)$ \\
\hline Reduced & $43(93)$ \\
\hline Absent & $3(7)$ \\
\hline \multicolumn{2}{|c|}{ Vibration sensation (foot) $(n=20)$} \\
\hline Normal & $0(0)$ \\
\hline Reduced & $20(100 \%)$ \\
\hline \multicolumn{2}{|c|}{ Achilles tendon reflexes: } \\
\hline Normal & $0(0)$ \\
\hline Diminished & $41(89)$ \\
\hline Absent & $5(11)$ \\
\hline \multicolumn{2}{|c|}{ Postural hypotension $(\mathrm{n}=20)$} \\
\hline $5-15 \mathrm{~mm} \mathrm{Hg}$ & $5(25)$ \\
\hline $16-30 \mathrm{~mm} \mathrm{Hg}$ & $3(15)$ \\
\hline
\end{tabular}

ELECTROPHYSIOLOGICAL STUDIES

These were performed bilaterally once every 2 years in all 46 patients using "Neuropack-II" (Nihon Kohden, Japan). Motor conduction velocity (MCV) and distal motor latencies (DMLs) were measured in median, ulnar, peroneal, and tibial nerves. Sensory nerve action potential latencies (DSLs) and amplitudes (SNAPs) were measured in the median and medial plantar nerves, averaging 60 stimulus responses. Laboratory normal ranges are shown in table 3.

\section{Results}

PATIENTS' CHARACTERISTICS (TABLE 1)

Of the whole group of 151 workers with occupational exposure and with raised lead concentrations, $46(30 \%)$ had features corresponding to the criteria for lead neuropathy. Of these 46 workers the mean age at presentation was 50 years and $65 \%$ were women. Their commonest occupations were soldering, oxyacetylene cutting of shipwrecks, and typesetting. Duration of 
Table 2 Average lead and porphyrin concentrations (mean (SD) (range)

\begin{tabular}{|c|c|c|c|}
\hline & Neuropathic group $(n=46)$ & Non-neuropathic group $(n=46)$ & $\begin{array}{l}\text { Recommended normal range } \\
\text { or maximum }\end{array}$ \\
\hline Duration of exposure (y) & $21.7(8-47)$ & $23.1(1-51)$ & \\
\hline Blood lead $(\mu \mathrm{g} / \mathrm{dl})$ & $63.93(18.27)(40-144)$ & $49.25(12.84)(26-90.7)$ & 40 \\
\hline Urinary lead $(\mu \mathrm{g} / \mathrm{dl})$ & $9.0 \pm 3.0)(2-17)$ & $6.0(2.0)(1-12)$ & 5.0 \\
\hline Urinary coproporphyrins ( $\mu \mathrm{g} / \mathrm{g}$ creatinine) & $66.71(38.41)(16.5-208)$ & $62.14(31.09)(15-176)$ & $20-80$ \\
\hline Urine aminolaevulinic acid ( $\mathrm{mg} / \mathrm{g}$ creatinine) & $1.54(0.39)(0.73-2.2)$ & $1.61(0.51)(0.14-2.83)$ & $0.5-2.5$ \\
\hline
\end{tabular}

occupational exposure ranged from 8 to 47 years (mean 21.7); most ranged from 11-20 years $(46 \%)$ or $21-30$ years $(30 \%)$. First neuropathic symptoms occurred between 7 and 45 years (mean 20.0 (SD 8.1)) after starting occupational exposure. Further occupational exposure to lead had been stopped after medical diagnosis of intoxication, on average 2.8 (SD 3.8) years before this study. Neuropathic symptoms remained in all 46 after stopping exposure, but in no case did symptoms progress significantly.

\section{LEAD AND PORPHYRIN CONCENTRATIONS (TABLE 2)}

Blood and urinary lead concentrations in the neuropathic patients were substantially raised above the recommended safe maxima. Urinary CPs were raised in 23 of 46 patients $(50 \%)$, urinary ALA in six of $46(13 \%)$, but generally only mildly. Both ALA and CP were raised in three of $46(7 \%)$. Neither blood nor urinary lead concentrations correlated significantly with CP or ALA concentrations (Pearson correlation coefficient). Lead and CP concentrations are presented also for a group of patients without neuropathic symptoms, with a similar average duration of lead exposure. Blood and urinary lead concentrations were about $25 \%$ lower in these non-neuropathic subjects, but their CP concentrations were similar to those in the neuropathic group. It should be noted that this group was generally less symptomatic and therefore subject to less surveillance.

\section{CLINICAL FEATURES OF POLYNEUROPATHY (TABLE 1)}

Paraesthesiae and pain or impaired sensation occurred to varying severity for all 46 neuropathic lead intoxicated patients. Pain and paraesthesiae always occurred in the feet, and also in the hands in $26(57 \%)$. Pinprick sensation on the feet or hands was always blunted. The duration of vibration sensation at the metatarsophalangeal joint was reduced to between 0 to 8 seconds in the 20 who were examined; both sides were symmetrically affected (right 3.2 (SD 1.7) seconds; left 3.1
(SD 1.9) seconds). Limb weakness and disability did not occur in any of the patients. The ankle tendon jerks were absent or reduced compared with other tendon reflexes. Postural hypotension of 5 to $15 \mathrm{~mm} \mathrm{Hg}$ (systolic) occurred in five (aged 43-66 years) and of $>15$ $\mathrm{mm} \mathrm{Hg}$ in three (aged 48-55 years) of the 20 tested. Cold sensations in the distal limbs and increased hand and foot sweating were noted by most. Vasomotor changes affecting skin colour were noted in the hands or feet of 21 $(46 \%)$. Other organ systems were involved in $45(98 \%): 44(96 \%)$ had mood or sleep disturbances, 22 ( $48 \%$ ) had arterial hypertension ( $\geqslant 140 \mathrm{~mm} \mathrm{Hg}$ systolic, or $\geqslant 90 \mathrm{~mm} \mathrm{Hg}$ diastolic, or both), 13 (28\%) from gastrointestinal disturbances, and 19 (41\%) had haematological abnormalities (reticulocytosis, basophilic stipling, or anaemia).

NERVE CONDUCTION STUDIES (TABLE 3)

Lead intoxicated neuropathic patients had, on average, prolonged DMLs and distal DSLs, with SNAP amplitudes at the bottom of the normal range in all nerves studied. Motor conduction velocities and compound muscle action potentials were normal. In four patients disparities between median and ulnar DMLs pointed to a superimposd carpal tunnel syndrome, and in two disparities in tibial and peroneal nerve conduction pointed to tarsal tunnel entrapment. Otherwise, there were no significant differences between the right and left sides for nerve conduction indices in the group as a whole (for example, median DML right 4.78 (SD 0.21) ms, left 4.75 (SD 0.33) ms; medial plantar SNAP right 4.83 (SD 0.26) $\mu \mathrm{V}$, left $4.66(\mathrm{SD} 0.30) \mu \mathrm{V})$.

CASE REPORT: ACUTE LEAD POISONING

A 45 year old man developed acute abdominal pain and underwent laparotomy and appendectomy, procedures which were uncomplicated. For at least 3 days his legs had been too weak to stand, and his hands too weak for feeding. On the fourth postoperative day he fainted on standing. He had also noted a headache for 2 months. Colicky abdominal pain continued

Table 3 Nerve conduction studies (mean (SD))

\begin{tabular}{|c|c|c|c|c|c|c|c|c|}
\hline \multirow[b]{2}{*}{$\begin{array}{l}\text { Investigated } \\
\text { indices in nerves }\end{array}$} & \multicolumn{2}{|l|}{ Median } & \multicolumn{2}{|l|}{ Ulnar } & \multicolumn{2}{|c|}{ Tibial/medial plantar } & \multicolumn{2}{|l|}{ Peroneal } \\
\hline & $\begin{array}{l}\text { Neuropathic } \\
\text { patients, } n=92 \\
\text { investigations }\end{array}$ & $\begin{array}{l}\text { Normal } \\
\text { values }\end{array}$ & $\begin{array}{l}\text { Neuropathic } \\
\text { patients, } n=92 \\
\text { investigations }\end{array}$ & $\begin{array}{l}\text { Normal } \\
\text { values }\end{array}$ & $\begin{array}{l}\text { Neuropathic } \\
\text { patients, } n=92 \\
\text { investigations) }\end{array}$ & $\begin{array}{l}\text { Normal } \\
\text { values }\end{array}$ & $\begin{array}{l}\text { Neuropathic } \\
\text { patients, } n=92 \\
\text { investigations }\end{array}$ & $\begin{array}{l}\text { Range of } \\
\text { normal values }\end{array}$ \\
\hline DML & $4.78(0.25)$ & $\leqslant 4.4$ & $3.78(0.26)$ & $\leqslant 3.4$ & $6.31(0.09)$ & $\leqslant 5.8$ & & \\
\hline $\mathrm{MCV}$ & $52.6(2.4)$ & $>45.0$ & $49.1(2.5)$ & $>45.0$ & $51.0(3.8)$ & $>45.0$ & $41.0(1.6)$ & $>42.0$ \\
\hline CMAP & $4.64(0.56)$ & $>2.0$ & $3.81(0.51)$ & $>2.0$ & $4.56(0.62)$ & $>2.0$ & $2.85(0.31)$ & $>2.0$ \\
\hline SNAP & $5.2(0.28)$ & $4-15$ & & & $4.75(0.31)$ & $4-12$ & & \\
\hline DSL & $5.12(0.18)$ & $<4.4$ & & & $6.23(0.28)$ & $<5.6$ & & \\
\hline
\end{tabular}

$\mathrm{DML}=$ Distal motor latency $(\mathrm{ms}) ; \mathrm{MCV}=$ motor conduction velocity $(\mathrm{m} / \mathrm{s}) ; \mathrm{MAP}=$ compound muscule action potential $(\mathrm{mV}) ; \mathrm{SNAP}=$ sensory nerve action potential $(\mu \mathrm{V}) ; \mathrm{DSL}=$ distal sensory latency $(\mathrm{ms})$. 
for 2 weeks. During the second week basophilic stippling of erythrocytes was noted with a falling haemoglobin $(138 \mathrm{~g} / \mathrm{dl}$ to $112 \mathrm{~g} / \mathrm{dl}$ over 8 days) and a raised urinary lead concentration $(9.0 \mu \mathrm{g} / \mathrm{dl})$ was detected. Before this illness the patient had worked for 3 years as an oxyacetylene cutter dismembering nine submarine hulks which contained $30 \%$ lead, $4 \%$ molybdenum, and traces of nickel, chromium, and vanadium; the high lead content of submarine hulls acts as a shock absorber. No ventilation or breathing equipment was used. During the month before this illness, his working practices had not changed, he had not taken medicine, and his alcohol consumption remained moderate. Two months after presentation the blood lead was $170 \mu \mathrm{g} / \mathrm{dl}$ (normal<40 $\mu \mathrm{g} / \mathrm{dl}$ ), 24 hour urinary lead was $12.0 \mu \mathrm{g} / \mathrm{dl}$ (normal<5 $\mu \mathrm{g} / \mathrm{dl}$ ), urinary ALA $21 \mathrm{mkg} / \mathrm{g}$ creatinine (normal 0.5$2.5 \mathrm{mkg} / \mathrm{g}$ ), and urinary CPs $2102 \mathrm{mg} / \mathrm{g}$ creatinine (normal $20-80 \mathrm{mg} / \mathrm{g}$ ). Intravenous chelation therapy was started at 2 months with $16 \mathrm{~g}$ EDTA (calcium disodium edetate). Appreciable limb weakness lasted 3 months. In retrospect he had noted mild tingling and numbness in his fingers and toes 2 weeks before presentation and mood and sleep disturbances which had continued intermittently. Examination showed a bluish "lead line" on the gums. Initial neurological examination after 2 months showed diminished Achilles tendon reflexes, stocking and glove reduction of superficial sensation, markedly reduced limb muscle strength, and hyperhidrosis of the palms and feet. Nerve conduction studies 2.5 months after presentation showed a median nerve DML of $5.2 \mathrm{~ms}$, MCV $52 \mathrm{~m} / \mathrm{s}$, DSL 5.0 $\mathrm{ms}$, and SNAP $6 \mu \mathrm{V}$. By 8 months after presentation the blood lead was $58 \mu \mathrm{g} / \mathrm{dl}$, urinary lead $4.0 \mu \mathrm{g} / \mathrm{dl}$, urinary ALA $1.3 \mathrm{mg} / \mathrm{g}$ creatinine, and urinary CP $34 \mu \mathrm{g} / \mathrm{g}$ creatinine. Examination at 21 months, when he still had limb pain and stiffness, showed slight weakness of small hand muscles, diminished ankle jerks, normal vibration and joint position sensations, distally reduced pinprick sensation, and a $25 \mathrm{~mm} \mathrm{Hg}$ postural drop in systolic blood pressure.

\section{Discussion}

Our patients had an unusually long duration of exposure to inorganic lead and showed neuropathic features different from those traditionally attributed to lead toxicity. Their mild sensory and autonomic polyneuropathy contrasts markedly with the traditionally described pure motor disorder, which particularly picks out overused muscle groups such as the wrist extensors. Only one previous study has reported a high occurrence of sensory symptoms $(49 \%)$ with a low rate of weakness $(11 \%)$ in patients chronically exposed to lead but many of those had been exposed to organic rather than inorganic lead. ${ }^{19}$ Patients with lead intoxication with subacute motor weakness usually improve after removal from a toxic source as was the case in our sole patient with a subacute motor disorder. By contrast we found no evidence that sensory neuropathic patients with chronic lead exposure improved during their first years after stopping exposure. Notably, their blood and urinary lead concentrations remained increased 4 years after removal from exposure, despite chelation therapy; elimination of lead from bone takes decades. Presumably this bone storage constituted a continuing endogenous source of lead toxicity to the nervous system. Many of our chronically exposed patients showed toxic effects on other body organs, such as the brain, cardiovascular system, gastrointestinal tract, and red blood cells.

No previous studies have reported on the neuropathic consequences of such long term exposure to inorganic lead. Previous studies of exposed workers with raised lead concentrations have not noted clinical neuropathic abnormalities, despite mild electrophysiological abnormalities. ${ }^{912}{ }^{13}$ However, those populations were much younger than ours and their mean duration of exposure, if recorded, was only 4.6 years ${ }^{12}$ compared with the average of 21.7 years for our patients. Thus, the potential for lead to damage directly the peripheral nervous system was substantially higher in our patients than in those reported previously. More direct comparison of the intensity of lead exposure between different studies is impossible. In particular there is no method for time averaged quantification of the concentration of lead in inhaled fumes during occupations such as metal cutting or lead smelting, or of oral ingestion because of poor hand cleaning. Undoubtedly many of our patients had been exposed to notably high densities of fumes or dust in poorly ventilated circumstances, and often with inadequate hand cleaning procedures. For instance the workplace lead concentrations found in 14 patients exceeded recommended maximum acceptable concentration values by 1.2 -fold to threefold in the air (normal $\leqslant 0.1 \mathrm{mg} / \mathrm{m}^{3}$ ), and by 670 -fold in the "protective" work clothes in two lead paint sanders and polishers. Most previously studied exposed workers have been men. The predominance of women in our neuropathic group simply represents their high representation in this working population rather than any particular female susceptibility to lead neuropathy; $65 \%$ of the polyneuropathy group were women compared with $57 \%$ of the group exposed to lead without polyneuropathy.

Previous electrophysiological studies have concentrated on groups of workers exposed to lead but generally free from neuropathic symptoms, or on those occasional patients with subacute motor weakness associated with lead toxicity. Minor changes in distal motor nerve conduction or CMAP amplitudes have been noted when the level of safe chronic occupational exposure was exceeded. ${ }^{19101213}$ Our patients showed similar mild abnormalities of motor conduction without clinical motor abnormalities. Sensory nerve conduction has been studied less often in lead exposure. Abnormalities of SNAP amplitude have not been reported, but slight slowing of sensory conduction has. ${ }^{13}$ Likewise, sensory conduction velocity was slightly prolonged in the median and tibial nerves of our patients, 
whereas the SNAP amplitudes were not diminished on average, although they were generally towards the bottom of the normal range. Sensory nerve action potentials measure the integrity of the fastest conducting large myelinated fibres. The relative normality of sensory conduction in our patients comes as little surprise given that it does not measure conduction along unmyelinated fibres, mediating sensations such as pinprick, which were those predominantly affected in our patients. Further support for the notion of involvement of predominantly unmyelinated fibre comes from our finding of autonomic abnormalities affecting limb skin and of postural hypotension. Occasionally electrophysiology showed coexisting carpal tunnel syndrome, of little surprise in this population of manual workers and noted previously. ${ }^{19}$

It is likely that two different neuromuscular syndromes can result from lead intoxication: a subacute predominantly motor syndrome and a chronic sensory and autonomic syndrome. Do these two lead induced syndromes have a different pathogenic basis? Electrophysiology provides little clue as studies of the subacute motor presentation largely antedate modern measurement of nerve conduction and mainly report denervation on EMG. ${ }^{40}$ In our sole patient with subacute motor weakness after high intensity short term lead exposure, studied 2 months after presentation, the distal motor latencies were mildly prolonged, motor conduction velocity was normal, and sensory conduction was slightly slowed. Surprisingly, these findings differ little from those in chronically exposed patients who are asymptomatic or who had mild sensory and autonomic features. The striking difference was the massive increase in porphyrins in our patient with subacute motor neuropathy compared with the inconsistent and generally insignificant porphyrin increases seen in our patients chronically exposed to lead with mild sensory and autonomic neuropathy. Relatively little is known about the pathogenesis of subacute muscle weakness in attacks of porphyria, the general consensus pointing to axonal degeneration. ${ }^{21-24}$ However, porphyric muscle weakness usually recovers more rapidly than would be accounted for by axonal regeneration, and possible impairment of muscle energy metabolism during porphyric attacks has not been investigated. Lead intoxication is known to cause multiple abnormalities of porphyrin metabolism. ${ }^{25}$ Furthermore, plumboporphyric muscle weakness occurs in the context of normal lead concentrations in those rare patients with ALA dehydrase deficiency. ${ }^{26}$

We conclude that lead intoxication may affect the neuromuscular system in two different ways. Firstly, the subacute predominantly motor syndrome traditionally associated with high dose lead intoxication is probably secondary to lead induced porphyria. Secondly, our patients with extremely long term lead intoxication manifested a mild sensory and autonomic polyneuropathy which probably reflects a direct neurotoxic effect of lead. Fortunately, future opportunities will be limited for studying the pathogenesis of neuromuscular diseases associated with lead intoxication given the introduction of extensive health and safety controls on workplace exposure.

We are grateful to Mrs E Vesma and Mrs J Wilkinson for preparing the manuscript.

1 Windebank AJ. Metal neuropathy. In: Dyck PJ, Thomas PK, Griffin JW, et al, eds. Peripheral neuropathy. 3rd ed. Philadelphia: WB Sanders, 1993:1549-70.

2 Saryan LA, Zenz C. Lead and its compounds. In: Zenz C, ed. Occupational medicine. 3rd ed. Mosby-Year Book. St Louis: CV Mosby, 1994:506-41.

3 Cullen MR, Robins JM, Eskenazi B. Adult inorganic lead intoxication: presentation of 31 new cases and a review of
recent advances in the literature. Medicine 1983;62:221-47.

4 Seto DSY, Freeman JM. Lead neuropathy in children. Am $\dot{f}$ Dis Child 1964;107:337-342.

5 Oh SJ. Lead neuropathy: Case report. Arch Phys Med Rehabil 1975;56:312-17.

6 Feldman RG, Niles IA, Kelly-Hayes M, et al. Peripheral neuropathy in arsenic smelter workers. Neurology 1979;29: neuropa

7 Albers JW, Kallenbach LR, Fine LJ, et al. Neurological abnormalities associated with remote occupational elemental mercury exposure. Ann Neurol 1988;24:651-9.

8 Davis LE, Standefer JC, Kornfeld M, et al. Acute thallium poisoning: toxicological and morphological studies of the nervous system. Ann Neurol 1981;10:38-44.

9 Catton MJ, Harrison MJG, Fullerton PM, et al. Subclinical neuropathy in lead workers. BMf 1970;ii:80-2.

10 Araki S, Honma T, Yanagihara S, et al. Recovery of slowed nerve conduction velosity in lead-exposed workers. Int Arch Occup Environ Health 1980;46:151-7.

11 Seppäläinen AM, Hernberg S. Sensitive technique for detecting subclinical lead neuropathy. $B r \quad \mathcal{F}$ Ind Med 1972;29:443-9.

12 Seppäläinen AM, Tola S, Hernberg S, et al. Subclinical neuropathy at "safe" levels of lead exposure. Arch Environ Health $1975 \cdot 30: 180-3$

13 Buchthal F, Behse F. Electrophysiology and nerve biopsy in men exposed to lead. Br F Ind Med 1979;36:135-47.

14 Eglite M, Veide A, Bake MA, et al. Health consequences of occupational exposure to lead in Latvia. Proceedings of the Latvian Academy of Science, Section B 1998;52:205-7.

15 Gorn LE. Method of determination of lead in biological samples. Fournal of Problems of Medical Chemistry 1982;6: 625-6.

6 Loon JC van. Selected methods for trace metal analysis: biological and environmental samples. In: Elving PJ, ed. istry and its applications. London; 1986:175-215.

17 Sousby J, Smith IL. A simplified method for the quantitative determination of urinary coproporphyrin in lead workers. Br F Ind Med 1974;31:72-4.

18 Semenova LS. Modification of detection of $\delta$-aminolevulinic acid dehydratase in red blood cells and urine. Laboratornoje delo 1985;11:687-9. (In Russian.)

19 Mitchell CS, Shear MS, Bolla KI, et al. Clinical evaluation of 58 organolead manufacturing workers.f Occup Environ Med 1996;38:372-8.

20 Simpson JA, Seaton DA, Adams JF. Response to treatment with chelating agents of anaemia, chronic encephalopathy, and myelopathy due to lead poisoning. I Neurol Neurosurg Psychiatry 1964;27:536-41.

21 Ridley A. The neuropathy of acute intermittent porphyria. $Q \mathcal{F}$ Med 1969;151:307-33.

22 Bosch EP, Pierach CA, Bossenmaier I, et al. Effect of hematin in porphyric neuropathy. Neurology 1997;27:1053-6.

23 Di Trapani G, Casali C, Tonali P, et al. Peripheral nerve findings in hereditary coproporphyria. Acta Neuropathol 1984;63:96-107.

24 Suarez JI, Cohen ML, Larkin J, et al. Acute intermittent porphyria: clinicopathologic correlation. Neurology 1997; 48:1678-83.

25 Straka JG, Rank JM, Bloomer JR. Porphyria and porphyrin metabolism. Annu Rev Med 1990;41:457-69.

26 Dyer J, Garrick DP, Inglis A, et al. Plumboporphyria (ALAD deficiency) in a lead worker: a scenario for potential diagnostic confusion. Br f Ind Med 1993;50:1119-21. 